\title{
PONUDBA E-IZOBRAŽEVANJA V SLOVENIJI V LETIH 2006 IN 2015
}

\section{POVZETEK}

$V$ članku so predstavljene značilnosti ponudbe e-izobraževanja za odrasle v Sloveniji v letih 2006 in 2015. Uvodoma so opisani nekatere značilnosti te oblike izobraževanja in njen razvoj. E-izobraževanje je oblika izobraževanja, ki je zaradi svoje odprtosti in fleksibilnosti še posebej primerna za odraslo populacijo. Za pregled stanja $v$ Sloveniji in primerjavo smo izbrali leto 2006, ko je bila objavljena zadnja analiza e-izobraževalne ponudbe v Sloveniji (Zagmajster, 2006), in leto 2015. Podatke smo pridobili z analizo izobraževalne ponudbe, ki je zbrana na spletnem portalu Kam po znanje Andragoškega centra Slovenije.

Ključne besede: e-izobraževanje, izobraževalni programi, izobraževanje odraslih, neformalno izobraževanje odraslih

\section{ANALYSIS OF E-LEARNING OPPORTUNITIES IN SLOVENIA DURING THE YEARS 2006 AND 2015 - ABSTRACT}

The author examines the characteristics of e-learning opportunities for adults in Slovenia during the years 2006 and 2015. At the outset, some of the characteristics of this form of education and its development are described. E-learning is a form of education, which is characterized by openness and flexibility, and is as such particularly suitable for the adult population. The year 2006 was chosen as a starting point because this was also the year when the last analysis of the e-learning provisions in Slovenia was published (Zagmajster, 2006). The author compared this year with the year 2015. Data were obtained from the catalogue of the educational offer, which can be accessed at the web portal "Kam po znanje? [Where to Get Knowledge?]”, the latter being is managed by Slovenian Institute for Adult Education.

Keywords: e-learning, educational programs, adult education, non-formal adult education

Tina Godina, godinatina@gmail.com

NežaVrhovec,nezyvrhovec@gmail.com 


\section{UVOD}

Preden se lotimo analize ponudbe e-izobraževanja v Sloveniji, si oglejmo nekatere temeljne značilnosti te pomembne oblike izobraževanja odraslih. ${ }^{1}$ E-izobraževanje se je uveljavilo na mnogih področjih, zato so tudi njegove definicije različne in neenotne. Bregar, Zagmajster in Radovan (2010) ugotavljajo, da so opredelitve e-izobraževanja pogosto precej ohlapne, saj kot tako definirajo »izobraževanje, pri katerem se uporablja IKT«, pa najsi bo to spletno učenje, virtualne učilnice, podajanje vsebin po internetu, video in zvočne vsebine ali izobraževalne oddaje. Nicholson (2007) vzrok za raznolikost opredelitev pripiše dejstvu, da ima e-izobraževanje različne pojavne oblike, odvisno od dejavnosti, v kateri se uveljavi - vojska, podjetništvo, storitveni sektor ali visokošolsko izobraževanje. Zato bomo opredelitev e-izobraževanja pojasnili s pomočjo Bregarjeve idr. (2010), ki ločuje e-izobraževanje v širšem in ožjem pomenu. E-izobraževanje v širšem pomenu je »vsako izobraževanje, ki vsebuje tehnološko komponento« (prav tam, str. 12). V tem primeru je kot e-izobraževanje pojmovana kakršnakoli oblika izobraževanja, ki za dopolnitev učnemu procesu uporablja IKT, pri tem pa konceptualna zasnova učnega procesa ostaja enaka. Avtorji (prav tam) za poimenovanje te vrste e-izobraževanja predlagajo termin delno tehnološko podprto izobraževanje. Druge značilnosti delno tehnološko podprtega izobraževanja so še parcialna in nepovezana uporaba IKT v učnem procesu, ki temelji na doktrini tradicionalnega izobraževanja, prav tako se ne spremeni obseg klasičnega, neposrednega poučevanja v učilnici. Drugo skupino pojmovanj e-izobraževanja - ožje zastavljena pojmovanja - lahko ponazorimo z Rosenbergovo opredelitvijo, da je za e-izobraževanje značilna uporaba spletnih tehnologij z namenom povečanja znanja ali izboljšanja izobraževalne aktivnosti. Bregar (2011) ožje pojmovano e-izobraževanje poimenuje kot celostno e-izobraževanje, katerega ključna značilnost je celostna vključenost tehnološke komponente izobraževanja $\mathrm{v}$ izobraževalni proces.

E-izobraževanje je tako ena izmed oblik študija oziroma izobraževanja na daljavo. E-izobraževanje je izobraževanje, ki poteka ločeno od mesta poučevanja ob uporabi sodobnih informacijskih in komunikacijskih tehnologij. Zato zahteva specifične tehnike načrtovanja izobraževalnih gradiv, poučevanja in komuniciranja.

\section{RAZVOJ E-IZOBRAŽEVANJA V SLOVENIJI}

Kaj pokaže zgodovinski pregled tega področja v Sloveniji? Ugotavljamo, da lahko za nekakšen zametek e-izobraževanja pri nas štejemo dopisno izobraževanje, ki se je pojavilo že po drugi svetovni vojni in so ga izvajale ljudske oziroma delavske univerze. Te so s svojimi programi želele omogočiti, da bi ljudje pridobili potrebno znanje in strokovne nazive. Dopisno izobraževanje je bilo zato v tistem času zelo popularno. Razširjeno je bilo do leta 1970, ko izobraževanje na daljavo rahlo zamre. Razlog je bil v tem, da so številne šole začele odpirati dislocirane oddelke, zato ni bilo potrebe po študiju na daljavo.

1 Analiza je nastala v okviru študija po magistrskem programu andragogika (FF UL). 
V začetku devetdesetih let 20. stoletja (1991-1993) so na Raziskovalnem in razvojnem centru univerze ter na Ekonomski fakulteti v Ljubljani potekale raziskave različnih konceptov izobraževanja na daljavo. V tem obdobju lahko vidimo pomemben prelom za razvoj e-izobraževanja v Sloveniji. Takrat je začela delovati Nacionalna projektna enota (NCP) za študij na daljavo na Ekonomski fakulteti v Ljubljani, ki je »poskušala [...] zagotavljati ustrezne razmere na državni ravni za razvijanje e-izobraževanja kot sodobne in učinkovite oblike izobraževanja « (Arh, Kovačič in Jerman-Blažič, 2006, str. 394). Leta 1994, ko je začela delovati NCP, je evropska komisija odobrila program PHARE z namenom izboljševanja kakovosti izobraževanja v posameznih državah. Projekt je trajal do leta 1999, vanj pa je bila vključena tudi Slovenija. Prek projekta PHARE se je leto kasneje (1995) na Ekonomski fakulteti v Ljubljani začel izvajati prvi študij na daljavo v Sloveniji, in sicer za prvi letnik Visoke poslovne šole, ki je obsegal deset predmetov.

$\mathrm{V}$ začetnem obdobju se je na nacionalni ravni vlagalo predvsem $\mathrm{v}$ informacijsko infrastrukturo, pozabilo pa se je na vsebinske komponente e-izobraževanja - tem je bil namenjen le majhen delež finančnih sredstev (Arh, Kokalj, Dinevski in Jerman-Blažič, 2008). V celotni zgodbi pa je treba omeniti nekatere pobude oziroma primere v praksi, ki so se izvajali v tem obdobju. Prva iniciativa je bil program Računalniško opismenjevanje. Prav ta je med letoma 1994 in 2000 zagotavljal Sloveniji, da je bila vedno na vrhu po vseh kazalcih uporabe IKT v procesu izobraževanja. Program se je ukinil leta 2002 (Arh idr., 2006; Arh idr., 2008).

V letih 1999-2005 je potekal projekt MIRK (Mladi in računalniška kreativnost). Namenjen je bil osnovnošolcem za prikaz osnovne uporabe IKT. V prvem letu izvajanja tega projekta je bil ustanovljen Center za razvoj študija na daljavo na Univerzi v Mariboru, katerega najpomembnejša naloga je bila, da je na področjih, kot sta odprto učenje in študij na daljavo, ponujal različne storitve, od tehničnih do svetovalnih. Velike zasluge za razvoj e-izobraževanja ima tudi Laboratorij za telekomunikacije Fakultete za elektrotehniko, kjer so razvili sistem e-izobraževanja E-CHO, ki ga uporabljajo v različnih ustanovah in podjetjih (Arh idr., 2006).

\section{METODOLOGIJA ZBIRANIA PODATKOV}

V prejšnjem poglavju smo izvedeli, da ima e-izobraževanje v Sloveniji svoj začetek $\mathrm{v}$ devetdesetih letih 20. stoletja. Za pregled stanja v Sloveniji in primerjavo pa nismo šli na sam začetek, ampak smo se ustavili v letu 2006, ko je M. Zagmajster napisala poročilo o raziskavi o pregledu študija na daljavo na področju izobraževanja odraslih v Sloveniji (Zagmajster, 2006). Te podatke smo primerjali s stanjem v obdobju od 1. januarja do 1. oktobra 2015, za katero smo podatke pridobili na spletni strani Andragoškega centra Slovenije z naslovom Kam po znanje - Pregled ponudbe izobraževanja odraslih (https://pregled.acs.si/). Na spletni strani je predstavljena ponudba izvajalcev izobraževanja odraslih za tekoče šolsko leto. 
Primerjavo na področju ponudnikov e-izobraževanja smo naredili glede na:

- vrsto ustanove,

- regijo,

- vrsto programa in

- vsebino izobraževalnega programa.

\section{REZULTATI ANALIZE ZBRANIH PROGRAMOV}

\section{Ponudniki e-izobraževanja glede na vrsto ustanove}

Kot lahko vidimo v Tabeli 1, se je število ponudnikov e-izobraževanja od leta 2006 do leta 2015 zelo povečalo, najbolj pa pri tem prednjačijo srednje šole (z ene na 45), razne ustanove, uvrščene pod kategorijo Drugo (z ene na 37), ljudske univerze (s šest na 28) in višje strokovne šole ( $\mathrm{z}$ dveh na 16).

Tabela 1: Ponudniki e-izobraževanja glede na vrsto ustanove

\begin{tabular}{|c|c|c|c|c|}
\hline & \multicolumn{2}{|c|}{2006} & \multicolumn{2}{|c|}{2015} \\
\hline & $\mathrm{N}$ & $\%$ & $\mathrm{~N}$ & $\%$ \\
\hline Javni zavod & 3 & 9,7 & 4 & 3 \\
\hline Knjižnica & 1 & 3,2 & 5 & 4 \\
\hline Ljudska univerza & 6 & 19,4 & 28 & 20 \\
\hline Center v podjetju & 2 & 6,5 & / & / \\
\hline Srednja šola & 1 & 3,2 & 45 & 32 \\
\hline Višja strokovna šola & 2 & 6,5 & 16 & 12 \\
\hline Zasebna organizacija/šola & 11 & 35,5 & / & / \\
\hline Fakulteta, akademija & 1 & 3,2 & 4 & 3 \\
\hline Zavod & 3 & 9,7 & I & / \\
\hline Drugo $^{2}$ & 1 & 3,2 & 37 & 27 \\
\hline SKUPAJ & 31 & 100,0 & 139 & 100 \\
\hline
\end{tabular}

Nekoliko manjše povečanje števila ponudnikov je opaziti pri knjižnicah (z ene na pet), fakultetah in umetniških akademijah (z ene na štiri) in javnih zavodih (povečanje s tri na štiri).

Podatkov o različnih zavodih, zasebnih organizacijah/šolah in centrih v podjetju nismo mogli primerjati, ker teh v rubrikah na spletni strani Kam po znanje nismo našli, zato je prikazan samo delež iz analize M. Zagmajster (2006).

2 Sem sodijo naslednje ustanove: enote za odrasle pri srednji šoli, društva, zveze društev, službe za izobraževanje v podjetju, druge organizacije, ustanove, univerze za tretje življenjsko obdobje, muzeji in galerije, inštituti, posebni izobraževalni centri, skladi, fundacije, visoke strokovne šole, zbornice, združenja in druge organizacije oziroma ustanove. 


\section{Ponudniki e-izobraževanja glede na regijo}

Kot lahko ugotovimo iz primerjave, se je število ponudnikov e-izobraževanja od leta 2006 do leta 2015 najbolj povečalo v osrednjeslovenski regiji, in sicer za več kot polovico (s 15 na 39). Sledijo ji podravska (s štiri na 11), gorenjska (s treh na devet) in pa savinjska regija (z enega na šest). Dvig števila ponudnikov je opaziti tudi v pomurski in koroški regiji, kjer v letu 2006 niso imeli nobenega ponudnika e-izobraževanja, v letu 2015 pa po dva.

Tabela 2: Ponudniki e-izobraževanja po regijah

\begin{tabular}{|l|r|r|r|r|}
\cline { 2 - 5 } \multicolumn{1}{c|}{} & \multicolumn{2}{c|}{2006} & \multicolumn{2}{c|}{2015} \\
\cline { 2 - 5 } \multicolumn{1}{c|}{} & $\mathrm{N}$ & $\%$ & $\mathrm{~N}$ & $\%$ \\
\hline Osrednjeslovenska & 15 & 48,4 & 39 & 53,4 \\
\hline Gorenjska & 3 & 9,7 & 9 & 12,3 \\
\hline Notranjsko-kraška & 0 & 0,0 & 0 & 0,0 \\
\hline Podravska & 4 & 12,9 & 11 & 15,1 \\
\hline Obalno-kraška & 1 & 3,2 & 2 & 2,7 \\
\hline Koroška & 0 & 0,0 & 2 & 2,7 \\
\hline Pomurska & 0 & 0,0 & 2 & 2,7 \\
\hline Savinjska & 1 & 3,2 & 6 & 8,2 \\
\hline Spodnjeposavska & 2 & 6,5 & 0 & 0,0 \\
\hline Goriška & 2 & 6,5 & 0 & 0,0 \\
\hline Jugovzhodna Slovenija & 2 & 6,5 & 2 & 2,7 \\
\hline Zasavska & 1 & 3,2 & 0 & 0,0 \\
\hline SKUPAJ & 31 & 100,0 & 73 & 100,0 \\
\hline
\end{tabular}

Zgolj za enega se je število ponudnikov povečalo v obalno-kraški regiji. Jugovzhodna Slovenija ostaja na enaki ravni kot v letu 2006 (dva ponudnika). Nasprotno pa se pravi upad števila ponudnikov kaže $\mathrm{v}$ spodnjeposavski, goriški in zasavski regiji. V notranjsko-kraški regiji pa ni bilo ne v letu 2006 ne v letu 2015 nobenega ponudnika e-izobraževanja.

\section{Ponudba e-izobraževanja glede na vrsto programa}

V nadaljevanju si poglejmo ponudbo e-izobraževanja glede na vrsto programa. Iz razpredelnice lahko razberemo, da se je za več kot polovico povečalo število programov za pridobitev formalne izobrazbe (z 21 na 56) in tistih pri usposabljanju za delo oziroma dopolnilnem izobraževanju (z dveh na 17). 
Tabela 3: Primerjava e-izobraževanja po vrsti programa

\begin{tabular}{|l|r|r|r|r|}
\cline { 2 - 5 } \multicolumn{1}{c|}{} & \multicolumn{2}{|c|}{2006} & \multicolumn{2}{c|}{2015} \\
\cline { 2 - 5 } \multicolumn{1}{c|}{} & $\mathrm{N}$ & $\%$ & $\mathrm{~N}$ & $\%$ \\
\hline Usposabljanje in spopolnjevanje za delo & 2 & 2 & 17 & 23 \\
\hline Splošno neformalno izobraževanje & 87 & 79 & $/$ & $/$ \\
\hline Pridobitev izobrazbe & 21 & 19 & 56 & 77 \\
\hline SKUPAJ & 110 & 100 & 73 & 100 \\
\hline
\end{tabular}

Pomanjkljivost zgornje tabele je odsotnost podatka o programih neformalnega izobraževanja za leto 2015, zato v tem delu ne moremo oceniti morebitnega napredka.

\section{Ponudba e-izobraževanja glede na izobraževalne vsebine}

Kar lahko razberemo iz razpredelnice, je upad števila programov po raznolikosti izobraževalnih vsebin. V zakup pa moramo vzeti to, da v primerjavi ni upoštevano celotno leto 2015, ampak je vključeno le obdobje devetih mesecev, od januarja do konca septembra oziroma začetka oktobra. Morda bi vključitev še treh nadaljnjih mesecev pokazala manjšo razliko med številom programov, ki se razlikujejo glede na izobraževalne vsebine.

Tabela 4: Primerjava programov e-izobraževanja glede na izobraževalne vsebine

\begin{tabular}{|c|c|c|c|c|}
\hline & \multicolumn{2}{|c|}{2006} & \multicolumn{2}{|c|}{2015} \\
\hline & $\mathrm{N}$ & $\%$ & $\mathrm{~N}$ & $\%$ \\
\hline Administrativna dejavnost & 5 & 5 & 0 & 0 \\
\hline Družboslovje & 1 & 1 & 6 & 8 \\
\hline Ekonomika & 6 & 5 & 0 & 0 \\
\hline Jeziki & 53 & 48 & 12 & 16 \\
\hline Knjižničarstvo in dokumentalistika & 1 & 1 & 0 & 0 \\
\hline Komunalne storitve & 1 & 1 & 1 & 1 \\
\hline Komuniciranje & 2 & 2 & 0 & 0 \\
\hline Obdelava in predelava kovin & 2 & 2 & 1 & 1 \\
\hline Osebnostna rast & 1 & 1 & 1 & 1 \\
\hline Poslovno finančna dejavnost & 5 & 5 & 19 & 26 \\
\hline Promet & 2 & 2 & 8 & 11 \\
\hline Psihologiia, pedagogika, andragogika & 7 & 6 & 0 & 0 \\
\hline Računalništvo in informatika & 23 & 21 & 5 & 7 \\
\hline Splošno izobraževanje & 1 & 1 & 1 & 1 \\
\hline Drugo $^{3}$ & 0 & 0 & 19 & 26 \\
\hline SKUPAJ & 110 & 100,0 & 73 & 100 \\
\hline
\end{tabular}

3 V rubriko Drugo sodijo naslednje vsebine, ki so bile najdene na spletni strani Kam po znanje za leto 2015 in jih ni bilo možno razvrstiti v nobeno kategorijo iz leta 2006: opismenjevanje, izobraževanje učiteljev (pet), umetnost (tri), pravne vede, naravoslovje, vede o živi naravi, fizikalne in kemijske vede, matematika in statistika, proizvodne tehnologije, arhitektura, urbanizem in gradbeništvo (pet), kmetijstvo, gozdarstvo in ribištvo, veterinarstvo, zdravstvo, socialno delo (tri), osebne storitve (frizerstvo, gostinstvo - tri), varovanje. 
Glede na podatke pa lahko povzamemo naslednje: največjo rast so doživeli programi z naslednjimi izobraževalnimi vsebinami: poslovno finančna dejavnost (s pet na 19), promet (z dveh na osem) in družboslovje ( $\mathrm{z}$ enega na šest). Upad števila programov pa je mogoče opaziti predvsem pri jezikih (s 53 na 12), računalništvu in informatiki (s 23 na pet) ter obdelavi in predelavi kovin ( $\mathrm{z}$ dveh na enega). Enako število programov ostaja pri splošnem izobraževanju, osebnostni rasti in komunalnih storitvah (po en program). Za psihologijo, pedagogiko in andragogiko, komuniciranje, knjižničarstvo, ekonomiko in administrativno dejavnost za leto 2015 nimamo podatkov, zato primerjave ne moremo narediti.

\section{ZAKLJUČEK}

Iz primerjave vseh podatkov izhaja, da se je število ponudnikov e-izobraževanja od leta 2006 pa do leta 2015 sicer povečalo, vendar pa je to povečanje manjše od pričakovanj. Pri tem so imele najpomembnejšo vlogo srednje šole, ljudske univerze in višje strokovne šole. Največje število in tudi največjo rast števila programov e-izobraževanja opažamo v osrednjeslovenski regiji - za več kot polovico -, sledijo ji podravska, gorenjska in savinjska regija. Opazili smo tudi, da se je od leta 2006 do leta 2015 število programov za pridobitev formalne izobrazbe in programov usposabljanja za delo okrepilo za več kot polovico. Če preidemo na izobraževalne vsebine, lahko povzamemo naslednje: najbolj je zraslo število programov s poslovno finančno vsebino, s področja prometa in družboslovja; upad pa so doživeli jezikovni programi in programi računalništva ter obdelave in predelave kovin.

Odprta seveda ostajajo številna vprašanja glede ponudbe e-izobraževanja pri nas. Najprej moramo poudariti, da podatki, dostopni na portalu Kam po znanje, niso popolni, saj je vpis v bazo povsem prostovoljen. To pomeni, da se v praksi izvaja več programov, kot jih objavlja ta portal. Kljub temu pa menimo, da rezultati niso optimalni. Glede na to, da prištevamo e-izobraževanje med tiste oblike izobraževanja, ki so zaradi možnosti fleksibilnosti, individualizacije in odprtosti še posebno primerne za odrasle, je razvoj v Sloveniji dokaj skromen. Težko bi zagovarjali tezo, da je za to kriva pomanjkljiva infrastruktura, saj je za to v Sloveniji razmeroma dobro poskrbljeno. Dodatne analize pa bi bile potrebne, da bi lahko odgovorili na vprašanje, ali je razloge za majhno ponudbo treba iskati v slabem didaktičnem poznavanju e-izobraževanja, nerazumevanju postopkov uvajanja takih programov v institucionalno ponudbo ali pa v dvomih o njegovi kakovosti. To stanje bi zagotovo izboljšalo povečanje usposabljanja učiteljev za to novo obliko izobraževanja in vključitev tega področja $\mathrm{v}$ študijske programe, ki izobražujejo bodoče učitelje in druge strokovnjake na področju izobraževanja. Zaključimo lahko z mislijo L. Bregar (2011), da lahko vseeno optimistično zremo v prihodnost e-izobraževanja v Sloveniji, saj statistični podatki kažejo visoko stopnjo uporabe naprednih komunikacijskih storitev ter interneta za izobraževalne namene in velik obseg priložnostnega učenja s pomočjo računalnika, še posebno pri mladih. 


\section{LITERATURA}

Arh, T., Kokalj, R., Dinevski, D. in Jerman-Blažič, B. (2008). Pregled stanja na področju e-izobraževanja v Sloveniji. Organizacija, 41(3), 155-167.

Arh, T., Kovačič, M. in Jerman-Blažič, B. (2006). Struktura ponudbe e-izobraževanja v Sloveniji. Organizacija, 39(6), 393-401.

Bregar, L. (2011). Trendi v e-izobraževanju ter dejavniki uspešnega in učinkovitega vpeljevanja v izobraževanje odraslih v Sloveniji. Andragoška spoznanja, 17(4), 44-59.

Bregar, L., Zagmajster, M. in Radovan, M. (2010). Osnove e-izobraževanja. Ljubljana: Andragoški center Slovenije.

Nicholson, P. (2007). A history of e-learning: Echoes of the pioneers. V B. Fernandez-Manjon (ur.), Computers and education: E-learning, from theory to practice (str. 1-11). Dordrecht: Springer.

Zagmajster, M. (2006). Pregled študija na daljavo na področju izobraževanja odraslih v Sloveniji. Ljubljana: Andragoški center Republike Slovenije. 